\title{
Electrochemical aptasensor for human osteopontin detection using a DNA aptamer selected by SELEX
}

\author{
Sofia G. Meirinho a, b, *, Luís G. Dias ${ }^{\text {c, d }}{ }^{\text {, António M. Peres }}{ }^{\text {a }}$, Lígia R. Rodrigues ${ }^{\text {b }}$ \\ a Laboratory of Separation and Reaction Engineering, Laboratory of Catalysis and Materials (LSRE-LCM), ESA, Instituto Politécnico de Bragança, Campus \\ Santa Apolónia, 5300-253 Bragança, Portugal \\ ${ }^{\mathrm{b}}$ CEB - Centre of Biological Engineering, University of Minho, Campus de Gualtar, 4710-057 Braga, Portugal \\ ${ }^{c}$ ESA - Instituto Politécnico de Bragança, Campus Santa Apolónia, 5300-253 Bragança, Portugal \\ ${ }^{\mathrm{d}}$ CQ-VR - Centro de Química - Vila Real, University of Trás-os-Montes, Apartado 1013, 5001-801 Vila Real, Portugal
}

\section{H I G H L I G H T S}

- A DNA aptamer against OPN, a tumor biomarker, selected by SELEX iterative in vitro process is reported for the first time.

- An electrochemical (square wave voltammetry) signal-off DNA aptasensor was designed exhibiting affinity towards OPN.

- The DNA aptasensor had satisfactory sensitivity and selectivity towards OPN, with low signal interferences from other proteins.

- The DNA aptasensor had a LOD of 1.3 $\pm 0.1 \mathrm{nM}$ (synthetic human plasma) within OPN levels found breast cancer patients.

- Preliminary results showed that DNA aptasensor can detect OPN in real human plasma, similarly to the standard ELISA method.

\section{A R T I C L E I N F O}

\section{Article history:}

Received 20 January 2017

Received in revised form 30 May 2017

Accepted 27 July 2017

Available online 29 August 2017

\section{Keywords:}

Osteopontin

SELEX

DNA aptamers

Screen-printed gold electrode

Electrochemical aptasensor
G R A P H I C A L A B S T R A C T

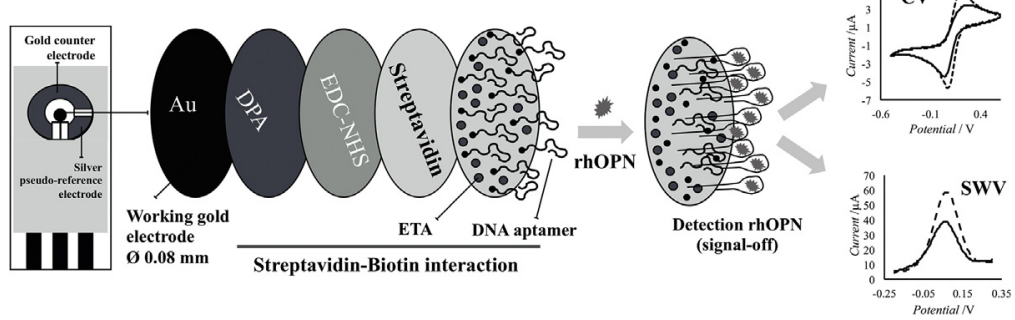

\footnotetext{
* Corresponding author. LSRE-LCM, Instituto Politécnico de Bragança, Campus Santa Apolónia, 5300-253 Bragança, Portugal.

E-mail address: sgmeirinho@ipb.pt (S.G. Meirinho).
} 
quantified similar OPN levels $(2.2 \pm 0.7$ and $1.7 \pm 0.1 \mathrm{nM}$, respectively). Thus, our aptasensor coupled with SWV represents a promising alternative for the detection of relevant breast cancer biomarkers.

(C) 2017 Elsevier B.V. All rights reserved.

\section{Introduction}

Osteopontin (OPN) is a matricellular protein, expressed by a variety of cell types and found in several biological fluids and tumor tissues [1,2]. The OPN contains around 314 amino acid residues subject to multiple post-translational modifications, thus resulting in a molecular weight range between 41 and $75 \mathrm{kDa}[1,3,4]$. The OPN is rich in aspartate, glutamate and serine residues. Besides, it contains several functional domains such as arginine-glycineaspartate (RGD), serine-valine-valine-tyrosine-glutamate-leucinearginine (SVVYGLR) and the thrombin cleavage site (RSK) [4-7]. High levels of OPN in serum or plasma have been detected in people suffering from cancer and may be associated with tumor progression, aggressiveness and metastasis [8-14]. Indeed, human OPN has been pointed as a potential biomarker in a number of cancers including breast, ovarian, prostate, lung, liver and colon [3,11,13-19]. Moreover, OPN has been considered as a possible therapeutic target for blocking tumor growth and subsequent metastasis [20-22]. Therefore, the detection of OPN can be used to monitor the disease progression and provide useful information about its prognosis [23]. Commonly, OPN detection in plasma samples is performed through enzyme-linked immunosorbent assay (ELISA). Bramwell et al. [11] quantified human OPN in plasma samples of patients with breast cancer using ELISA. The average OPN concentration determined was $46 \mathrm{ng} \mathrm{mL}^{-1}(\sim 0.7 \mathrm{nM})^{1}$ ranging from $22.6 \mathrm{ng} \mathrm{mL}^{-1}(\sim 0.4 \mathrm{nM})^{1}$ to $290 \mathrm{ng} \mathrm{mL}^{-1}(\sim 4.5 \mathrm{nM})^{1}$. For patients with metastatic breast cancer or with recurrent breast cancer, higher mean OPN levels were found $60.7 \mathrm{ng} \mathrm{mL}^{-1}(\sim 0.9 \mathrm{nM})^{1}$, ranging from $23.3 \mathrm{ng} \mathrm{mL}^{-1}(\sim 0.4 \mathrm{nM})^{1}$ to $543 \mathrm{ng} \mathrm{mL}^{-1}(\sim 8.4 \mathrm{nM})^{1}$ Despite the usefulness of ELISA, alternative methods ought to be developed for the detection of OPN at the lower concentrations that are usually found in early stages of the disease. Advances in the biosensors field, namely the possibility of designing new and extremely specific bioreceptors (e.g. aptamers), make them very promising for the detection of low levels of protein biomarkers, such as OPN, in plasma or blood samples [24-29].

Aptamers are short single-strand DNA (ssDNA) or RNA oligonucleotides (20-100 nucleotides) that can fold into unique tertiary structures [30,31]. It is possible to isolate aptamers, from an oligonucleotide library, with high affinity and specificity to a wide variety of targets, ranging from small molecules to large proteins, using the Systematic Evolution of Ligands by Exponential Enrichment (SELEX) methodology [32,33]. Usually 5 to 15 cycles of selection are necessary to isolate one or few aptamers (RNA or DNA) that possess the highest affinity and specificity to the desired target [34]. Overall the use of aptamers as bioreceptors in biosensors is gaining an increased interest, especially as alternatives to antibodies, mainly due to their unique features. Aptamers are easy to produce and synthesize; present a good stability over a wide range of $\mathrm{pH}$, temperature and/or storage conditions; are resistant to denaturation and degradation; are amenable to chemical modifications, thus enabling their immobilization in several surfaces; and can be labelled with fluorophores, and other tags facilitating their

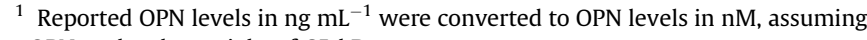
an OPN molecular weight of $65 \mathrm{kDa}$.
}

applications as bioreceptors in biosensors [25,35-37].

Mi et al. [20] described the first RNA aptamer against OPN that was used by Cao et al. [38] to develop an electrochemical aptasensor using a pyrolytic graphite disk electrode (3.0 mm diameter), functionalized with AuNPs. The human OPN detection limit achieved by SWV was $10.7 \mathrm{ng} \mathrm{mL}^{-1}(\sim 0.2 \mathrm{nM}){ }^{2}$ The aptasensor high sensitivity could be attributed to the use of nanoparticles that increase the superficial area available for aptamers immobilization [39]. However, these strategies increase the biosensor cost and can affect its reproducibility and performance when complex samples are used [40]. Recently, a voltammetric aptasensor, based on the same RNA aptamer, was used to detect human OPN with satisfactory performance, reproducibility and stability but with a greater detection limit $(3.7 \pm 0.6 \mathrm{nM})[41]$. Also, the RNA aptasensor was sensitive to thrombin, a protein that is also present in human blood and serum, which could be a drawback when real samples are used. Hence, herein it is reported for the first time the isolation and characterization of a high affinity DNA aptamer for human OPN, through SELEX. The binding affinity of the selected DNA aptamer was determined by fluorescence assays. Moreover, this aptamer was used as bioreceptor for the development of a label-free electrochemical DNA aptasensor to detect human OPN. The aptasensor was tested by cyclic voltammetry (CV) and SWV and its performance was evaluated using standard solutions prepared in PBS buffer ( $\mathrm{pH}$ 7.4), synthetic and real human plasma samples.

\section{Experimental section}

\subsection{Material and reagents}

Nitrocellulose membranes $(0.45 \mu \mathrm{m})$ were purchased from Whatman. dNTP mix (containing dATP, dCTP, dGTP, and dTTP ( $4 \mathrm{mM}$ each) ) and Taq DNA polymerase $\left(5 \mathrm{U} \mu \mathrm{L}^{-1}\right)$ were obtained from New England Biolabs. TOPO TA cloning Kit was acquired from Invitrogen. GRS Plasmid Purification Kit was purchased from Grisp Research Solutions. Kieselgur, sodium acetate, urea, 3,3dithiodipropionic acid (DPA), N-(3-dimethylaminopropyl)-N-ethylcarbodiimide hydrochloride (EDC), N-hydroxysuccinimide (NHS), ethanolamine (ETA), sulfuric acid (purity $=99.999 \%$ ) and synthetic human plasma (P9523) were obtained from Sigma-Aldrich. Potassium hexacyanoferrate (III) $\left[\mathrm{K}_{3} \mathrm{Fe}(\mathrm{CN})_{6}\right]$ and potassium hexacyanoferrate (II) $\left[\mathrm{K}_{4} \mathrm{Fe}(\mathrm{CN})_{6}\right]$ were obtained from Acros Organics and potassium dihydrogen phosphate $\left(\mathrm{KH}_{2} \mathrm{PO}_{4}\right)$ from Merck. Sodium chloride $(\mathrm{NaCl})$, potassium chloride $(\mathrm{KCl})$, sodium hydrogen phosphate $\left(\mathrm{Na}_{2} \mathrm{HPO}_{4}\right)$ and Ethanol were acquired from Panreac. Recombinant human osteopontin (rhOPN, $65 \mathrm{kDa}$, isoelectric point $(\mathrm{p} I)=3.5)$, recombinant bovine osteopontin (rbOPN, $60 \mathrm{kDa}$, $\mathrm{pI}=3.59-4.46)$ and Quantikine ELISA kit as well as the Quantikine Immunoassay Control Set 565 for Human Osteopontin were purchased from R\&D Systems. Thrombin from human plasma (THR, $37.4 \mathrm{kDa}, \mathrm{pI} 7-7.6$ ), bovine serum albumin (BSA, $66 \mathrm{kDa}, \mathrm{pI}=4.7$ ), lysozyme from chicken egg white (LYS, $14.3 \mathrm{kDa}, \mathrm{pI}=10-11$ ) and streptavidin were obtained from Sigma-Aldrich. A real human

\footnotetext{
${ }^{2}$ Reported OPN levels in $\mathrm{ng} \mathrm{mL}^{-1}$ were converted to OPN levels in $\mathrm{nM}$, assuming an OPN molecular weight of $65 \mathrm{kDa}$.
} 
plasma sample, belonging to a 46 -year-old patient with an invasive ductal primary tumor was used to evaluate the aptasensor herein developed. This sample was collected in 2015 at the Hospital of Braga (Portugal). This study was approved by the ethics committee of the University of Minho and Hospital of Braga and the sample was collected after the patient signing an informed consent.

\subsection{Solutions}

All solutions were prepared using Milli-Q grade water (18.2 M $\Omega$ ) purified by a milli-QTM system (Millipore). Phosphate buffer saline (PBS) solution (137 mM NaCl, $2.7 \mathrm{mM} \mathrm{KCl}, 8.1 \mathrm{mM} \mathrm{Na}_{2} \mathrm{HPO}_{4}$ and $1.47 \mathrm{mM} \mathrm{KH}_{2} \mathrm{PO}_{4}$ ) with an adjusted $\mathrm{pH} 7.6$ was used for the selection/isolation and characterization of the DNA aptamer and with pH 7.4 for the development of the electrochemical aptasensor. A solution of urea $(7 \mathrm{M})$ was prepared in PBS buffer $\mathrm{pH} 7.6$ (elution buffer). EDC (200 $\mathrm{mM})$ and NHS $(100 \mathrm{mM})$ stock solutions were prepared and stored at $-20{ }^{\circ} \mathrm{C}$ until use. Stock solution of streptavidin ( $1 \mathrm{mg} \mathrm{mL}^{-1}$ ) was prepared in PBS ( $\mathrm{pH} \mathrm{7.4)} \mathrm{and} \mathrm{stored}$ at $-20^{\circ} \mathrm{C}$. Stock solutions of DPA $(200 \mathrm{nM})$ and ETA $(100 \mathrm{mM})$ were stored at $4{ }^{\circ} \mathrm{C}$. Stock solutions of each protein were prepared according to the manufacturer specifications and stored at $-20{ }^{\circ} \mathrm{C}$. The protein working solutions were obtained by adequate dilutions with PBS buffer ( $\mathrm{pH} 7.4$ ) and stored at $4{ }^{\circ} \mathrm{C}$ until use. The electrochemical probe $\left[\mathrm{Fe}(\mathrm{CN})_{6}\right]^{3-/ 4-}$, consisting of $5 \mathrm{mM}$ of $\mathrm{K}_{3} \mathrm{Fe}(\mathrm{CN})_{6}$ and $\mathrm{K}_{4} \mathrm{Fe}(\mathrm{CN})_{6}(1: 1)$, and $\mathrm{KCl}(10 \mathrm{mM})$ in $\mathrm{PBS}(100 \mathrm{~mL})$, with an adjusted $\mathrm{pH}$ of 7.4, was prepared daily. Stock solutions of DNA aptamer $(100 \mu \mathrm{M})$ were prepared with RNase water and stored at $-20{ }^{\circ} \mathrm{C}$. The working solutions were prepared before each assay by dilution of those solutions with fresh PBS and stored at $4{ }^{\circ} \mathrm{C}$ until use. Before the fluorescence assays and immobilization on the gold working electrode, the DNA aptamer was subjected to a temperature treatment $\left(95^{\circ} \mathrm{C}\right.$ during $5 \mathrm{~min} ; 4^{\circ} \mathrm{C}$ for $5 \mathrm{~min}$ and $10 \mathrm{~min}$ at room temperature) to obtain an adequate structure flexibility of the aptamer enabling its interaction with streptavidin on the gold electrode surface.

\section{3. ssDNA library, primers and aptamer sequences}

A 70-base single-stranded DNA (ssDNA) library purified by polyacrylamide gel electrophoresis (PAGE) containing $10^{15}$ random sequences and the primer-binding sites were synthesized by Alfagene (Portugal). Each sequence of the library contains a central region of 30 random nucleotides (nt) flanked by two $20 \mathrm{nt}$ primer hybridization sites (5'- GGG GGT GGT ACC AGA GAT GC-N 30 -CAG AGA GGA GGT ACC GTG GG-3'). A forward primer ( $5^{\prime}$ - GGG GGT GGT ACC AGA GAT GC- $\left.3^{\prime}\right)$ and a reverse primer (5'- CCC ACG GTA CCT CCT CTC TG-3') were used in the PCR amplification of the selected aptamer pool. The selected DNA aptamer sequence was modified with 6-carboxyfluorescein (5'-6-FAM- TGT GTG CGG CAC TCC AGT CTG TTA CGC CGC- $\left.3^{\prime}\right)$ and biotinylated in the $5^{\prime}$-end ( $5^{\prime}$-Biotin-TGT GTG CGG CAC TCC AGT CTG TTA CGC CGC-3'). These modified sequences were provided by Integrated DNA Technologies (Belgium).

\subsection{Apparatus and electrodes}

The $\mathrm{pH}$ was measured using a $\mathrm{pH}$ meter (iHANNA instruments pH 211). ssDNA and DNA plasmid were quantified using a Nanodrop 1000 (Thermo Scientific). The fluorescence measurements were conducted in 96-dark-well plates using an ELISA reader (Synergy HT, BIO-TEK, IZASA) equipped with thermostat holding temperature control (accuracy of $\pm 0.1{ }^{\circ} \mathrm{C}$ ) and filters configured to a wavelength of $492 \mathrm{~nm}$ for excitation and $518 \mathrm{~nm}$ for emission. The Gen5 ${ }^{\mathrm{TM}}$ data analysis software was used for collecting microplate data. Electrochemical measurements were carried out at room temperature with a Potentiostat-Galvanostat device (PG580, Uniscan Instruments). Screen printed gold electrodes (SPGEs) were purchased from DropSens (Spain) and consisted in a threeelectrode system with a gold working electrode (diameter of $0.8 \mathrm{~mm}$, reference DRP-CX220), a gold counter or auxiliary electrode and a silver pseudo-reference electrode.

\subsection{Procedures}

\subsubsection{SELEX methodology}

The selection of aptamers able to specifically bind rhOPN demands several cycles of isolation using a random ssDNA library $\left(10^{14}-10^{15}\right.$ different sequences) that interacts with the protein previously immobilized on a Kieselgur support ( $25 \mathrm{mg}$ ), in each cycle. Before immobilization, this support was washed three times with PBS buffer ( $\mathrm{pH} \mathrm{7.6)}$ ) and centrifuged at $13500 \mathrm{rpm}$ during $5 \mathrm{~min}$. Depending on the selection cycle, decreasing rhOPN concentrations were used: $154 \mathrm{nM}$ for the $1^{\text {st }}$ to the $4^{\text {th }}$ cycle; $77 \mathrm{nM}$ for the $5^{\text {th }}$ to the $8^{\text {th }}$; and $38 \mathrm{nM}$ for the last two cycles. The pre-washed Kieselgur support was inoculated with the adequate rhOPN concentrations for $6 \mathrm{~h}$ at $37^{\circ} \mathrm{C}$ with gentle agitation (130 rpm). Then, it was washed three times with PBS buffer ( $\mathrm{pH} 7.6$ ) and centrifuged at $13500 \mathrm{rpm}$ for $5 \mathrm{~min}$. To confirm the success of the immobilization step, the supernatant was collected and analyzed by polyacrylamide gel electrophoresis (PAGE). The Kieselgur support with immobilized rhOPN was dried at $37^{\circ} \mathrm{C}(\approx 18 \mathrm{~h})$ and was then ready to be used for inoculation with the ssDNA library. In each selection cycle the ssDNA pool was prepared as follows. First, the ssDNA pool in PBS buffer ( $\mathrm{pH} 7.6$ ) was denatured (heating to $95^{\circ} \mathrm{C}$ for $5 \mathrm{~min}$ ) and then immediately cooled to $4{ }^{\circ} \mathrm{C}$ for $15 \mathrm{~min}$, and finally kept at room temperature for $5 \mathrm{~min}$. Second, the re-natured ssDNA pool was filtered through a $0.45-\mu \mathrm{m}$ nitrocellulose filter to remove all filter-binding molecules (negative selection). Afterwards, the ssDNA library ( $1^{\text {st }}$ cycle) or the DNA bound rhOPN ( $2^{\text {nd }}$ to $9^{\text {th }}$ cycle $)$ was incubated with the immobilized rhOPN. These DNA solutions contained approximately $5 \mu \mathrm{M}$ in $1^{\text {st }}$ cycle; $7 \mu \mathrm{M}$ in the $2^{\text {nd }}$ to the $5^{\text {th }}$ cycles; $3 \mu \mathrm{M}$ in the $6^{\text {th }}$ to the $9^{\text {th }}$ cycles; and $1 \mu \mathrm{M}$ in the $10^{\text {th }}$ cycle. Following $4 \mathrm{~h}$ of incubation with the rhOPN (37 ${ }^{\circ} \mathrm{C}$ and $130 \mathrm{rpm}$ ), three washing steps with PBS buffer $(\mathrm{pH} 7.6)$ (centrifuged at $13500 \mathrm{rpm}$ during $5 \mathrm{~min}$ ) were performed to remove the unbound ssDNA. The bound ssDNA was eluted using a urea solution (7 M) and heat treatment $\left(95^{\circ} \mathrm{C}\right.$ for $5 \mathrm{~min}$ ) twice. The eluted ssDNA was precipitated by adding sodium acetate $(0.3 \mathrm{M})$ and $2.5 \mathrm{vol}$ of $95 \%$ ethanol; centrifuged at $13500 \mathrm{rpm}$, at $4{ }^{\circ} \mathrm{C}$ for $5 \mathrm{~min}$, and the pellet was washed twice with $70 \%$ ethanol. The recovered ssDNA was then amplified by PCR, ethanol-precipitated (as described above), and separated into single-stranded sequences (through heat treatment at $95{ }^{\circ} \mathrm{C}$ for $10 \mathrm{~min}$ ) for the next selection cycle. The final concentrations used in the PCR reaction were as follows: PCR buffer $(1 \mathrm{x})$, dNTP mix $(200 \mu \mathrm{M})$, forward primer and reverse primer $(0.4 \mu \mathrm{M}$ each), ssDNA pool (10-100 ng $\left.\mu \mathrm{L}^{-1}\right)$, and Taq DNA polymerase $(2.5$ $\left.\mathrm{U} \mu \mathrm{L}^{-1}\right)$. The initial denaturation step was conducted at $95{ }^{\circ} \mathrm{C}$ for $90 \mathrm{~s}$, proceeded by 30 cycles (denaturation, annealing and extension) at $95^{\circ} \mathrm{C}$ for $1 \mathrm{~min}, 53^{\circ} \mathrm{C}$ for $30 \mathrm{~s}$ and $72{ }^{\circ} \mathrm{C}$ for $30 \mathrm{~s}$, followed by a final extension at $72{ }^{\circ} \mathrm{C}$ for $2 \mathrm{~min}$ and then temperature was lowered to $4{ }^{\circ} \mathrm{C}$. After the $10^{\text {th }}$ selection cycle, the ssDNA pool recovered was cloned using the TOPO TA Cloning Kit. Nineteen colonies were randomly picked, purified and sequenced. Plasmids were purified using the GRS Plasmid Purification Kit and were sequenced at Macrogen Corporation (The Netherlands). The secondary structure analysis of the isolated aptamers was established using the MFold online available tool (http://mfold.rna.albany.edu/? $\mathrm{q}=$ mfold/DNA-Folding-Form) setting up the conditions $\mathrm{Na}^{+}$concentration of $0.146 \mathrm{M}$ at $37^{\circ} \mathrm{C}$ [42]. 


\subsubsection{Determination of the isolated DNA aptamer affinity to rhOPN}

The DNA aptamer C10K2 modified with 6-carboxyfluorescein (FAM) in the $5^{\prime}$-end was subjected to heat treatment $\left(95^{\circ} \mathrm{C}\right.$ during $5 \mathrm{~min}, 4^{\circ} \mathrm{C}$ for $5 \mathrm{~min}$ and $10 \mathrm{~min}$ at room temperature) before each fluorescence assay. Initially, different concentrations of FAMDNA aptamer were used to determine the contribution of the free aptamer to the overall fluorescence and to later estimate its concentration in the aptamer-protein complex studies. The DNA aptamer concentrations (varying from 2.5 to $100 \mathrm{nM}$ ) were stored/ incubated for $30 \mathrm{~min}$ or $4 \mathrm{~h}$ at room temperature. Afterwards, these solutions were excited at $492 \mathrm{~nm}$ and the fluorescence was measured at $518 \mathrm{~nm}$. These assays allowed establishing the calibration curves that relate the fluorescence intensity and FAM-DNA aptamer concentrations for both incubation times. To determine the fluorescence intensity of the aptamer-protein complexes, the FAM-DNA aptamer concentration was fixed by varying the rhOPN concentrations. In each fluorescence assay, $60 \mu \mathrm{L}$ solution of FAMDNA aptamer $(20 \mathrm{nM})$ were incubated with the same volume of different concentrations of rhOPN $(0,3,10,22,100,300$ and $370 \mathrm{nM}$ ) prepared in the same buffer $[43,44]$, in 96-dark-well plates. The mixtures were incubated at room temperature for two different incubation times. The mixture was excited at $492 \mathrm{~nm}$ and the fluorescence was measured at $518 \mathrm{~nm}$. The analysis of the fluorescence data and the confirmation of the aptamer-rhOPN complex formation by means of dissociation constant $\left(K_{\mathrm{d}}\right)$ estimation was performed as previously described [41] and were statistically analyzed using the Z-test [45].

\subsubsection{Development and evaluation of the DNA aptasensor}

The DNA aptasensor was developed according to the procedure described by Meirinho et al. [41]. Briefly, it includes the cleaning and functionalization with streptavidin and immobilization of the isolated DNA aptamer onto the working electrode surface via streptavidin-biotin interaction, followed by the incubation of the rhOPN protein with the aptamer. Despite some complexity of the procedure, the aptamer immobilization via streptavidin-biotin interaction has been chosen based on the known advantages of the methodology, previously reported in the literature [46-50]. These include the need of very low amounts of biotinylated aptamer [47]; the fact that it is less affected by changes of buffer concentration, $\mathrm{pH}$, denaturants and high temperatures; as well as the decrease of non-specific adsorption and improvement of the signal-noise ratio [48,49]. However, it is important to mention that other options could have been evaluated to immobilize the aptamer onto the gold electrode surface, such as via Au-S bond for instance.

2.5.3.1. Cleaning and functionalization of the working electrodes. The electrode was electrochemically cleaned by a series of oxidation and reduction cycles using three solutions $\left(\mathrm{H}_{2} \mathrm{SO}_{4}(0.5 \mathrm{M}), \mathrm{KCl}\right.$ $(0.01 \mathrm{M}) / \mathrm{H}_{2} \mathrm{SO}_{4}(0.1 \mathrm{M})$ and $\left.\mathrm{H}_{2} \mathrm{SO}_{4}(0.05 \mathrm{M})\right)$, under a potential range between -0.3 and $+1.5 \mathrm{~V}$ at a scan rate of $0.1 \mathrm{~V} \mathrm{~s}^{-1}$ until a representative cyclic voltammogram of a clean gold electrode was obtained. To functionalize the cleaned working electrode for the DNA aptamer immobilization, the electrode was incubated with DPA during $30 \mathrm{~min}$ at room temperature and then rinsed with deionized water for $1 \mathrm{~min}$. The carboxylic groups of the selfassembled monolayer formed were activated with EDC and NHS $(1: 1 \mathrm{v} / \mathrm{v})$ during $60 \mathrm{~min}$ at room temperature. Then, the working electrode was exposed to a streptavidin solution overnight at $4{ }^{\circ} \mathrm{C}$, enabling the binding of the amine groups. Finally, the functionalized working electrode was exposed with ETA during $20 \mathrm{~min}$ at room temperature to block any remaining active carboxyl groups.

2.5.3.2. Immobilization of the DNA aptamer and interaction with the protein. Prior to the immobilization, the DNA aptamer solution prepared in PBS buffer was subjected to heat treatment $\left(95{ }^{\circ} \mathrm{C}\right.$ during $5 \mathrm{~min}, 4^{\circ} \mathrm{C}$ for $5 \mathrm{~min}$ and $10 \mathrm{~min}$ at room temperature) to obtain an adequate flexible aptamer structure for interacting with the streptavidin on the gold electrode surface. Then, DNA aptamer ( $5 \mu \mathrm{L}, 4 \mathrm{nM}$ ) was placed on the cleaning working electrode, followed by a rinsing step with PBS buffer $(\mathrm{pH} 7.4)$ to remove the unbound DNA aptamer. Next, rhOPN ( $5 \mu \mathrm{L}, 1540 \mathrm{nM})$ was dropped on the working electrode and kept during $60 \mathrm{~min}$ (incubation time) for enabling the formation of aptamer-protein complex. After that, the electrode surface was washed with PBS solution to remove the unbound protein. Details regarding the optimal concentration of DNA aptamer and the incubation time for the formation of aptamer-protein complex are given as supplementary material.

2.5.3.3. Evaluation of the DNA aptasensor in standard solutions. The sensitivity of the aptasensor was evaluated using rhOPN solutions prepared by serial dilutions in PBS at pH 7.4. The concentrations tested were 25, 50, 100, 200, 400, 801 and $1540 \mathrm{nM}$. Several SPGEs modified with DNA aptamer $(4 \mathrm{nM})$ were incubated with different rhOPN standard solutions during $60 \mathrm{~min}$ at room temperature. The sensitivity of aptasensor was evaluated through the calculation of the detection limit (LOD) and quantification limit (LOQ), based on the linear relationship obtained between relative current change $(\Delta I \%)$ values of the oxidation peak current and the different rhOPN concentrations through the equations LOD $=3 \mathrm{x}$ $\mathrm{SD} / \mathrm{b}$ and $\mathrm{LOQ}=10 \times \mathrm{SD} / \mathrm{b}$, respectively, where $\mathrm{SD}$ is the standard deviation of the intercept and $b$ is the average slope of the regression line [51].

The stability, reproducibility, reusability and specificity of the aptasensor were examined by CV. The specificity of the aptasensor was established by measuring and comparing the response of the DNA aptamer to rhOPN and to other non-specific proteins with different molecular weights (MW) and isoelectric points ( $\mathrm{PI}$ ). Different SPGE modified with DNA aptamer (4 nM) were tested with each individual protein, all at a concentration of $200 \mathrm{nM}$. The non-specific proteins tested include BSA, THR, LYS and rbOPN. The stability of the aptasensor was investigated over time during 20days by using three SPGE modified with 4 nM DNA aptamer and further incubated with $1540 \mathrm{nM}$ rhOPN. The aptasensor was stored at $4{ }^{\circ} \mathrm{C}$ and subjected to electrochemical measurements every 5 days. The reproducibility of the aptasensor was studied at a rhOPN concentration of $200 \mathrm{nM}$ and $1540 \mathrm{nM}$ using five different SPGE prepared in different days and three different SPGE prepared in the same days. The reusability of the aptasensor was evaluated through the analysis of successive cycles of regeneration of the binding surfaces. To regenerate the aptasensor, $\mathrm{NaCl}(2 \mathrm{M})$ and urea (7 M) were evaluated. Three different SPGE modified with DNA aptamer were incubated with rhOPN (1540 nM), then incubated with the regenerate reagent ( $2 \mathrm{~min}$ at room temperature) and then again incubated with rhOPN for 5 times. The cyclic voltammogram was recorded before and after the incubations with the regeneration reagent.

2.5.3.4. Evaluation of the DNA aptasensor in complex biological samples. The potential ability of the DNA aptasensor to detect rhOPN was further evaluated using synthetic human plasma samples and both CV and SWV techniques and in real human plasma sample applying only the SWV technique. Two different assays were carried out using different SPGEs modified with DNA aptamer. First, increased known amounts of rhOPN were added to synthetic human plasma solutions and the sensitivity was evaluated through the calculation of the LOD and LOQ values. Afterwards, a series of the synthetic human plasma solutions and real human plasma solutions spiked with rhOPN solutions of known concentrations were prepared to estimate the rhOPN recovery. The results obtained 
using the aptasensor were compared with standard EnzymeLinked Immunosorbent Assay (ELISA) method using a comercial available Quantikine ELISA kit, following the guidelines of the manufacturer.

2.5.3.5. Electrochemical measurements. All electrochemical measurements were performed at room temperature, using $\left[\mathrm{Fe}(\mathrm{CN})_{6}\right]^{3-1}$ 4- solution $(60 \mu \mathrm{L})$ as electrochemical probe, in which the three electrodes (working, counter and reference) were dipped. The electrochemical analysis was performed by CV and SWV. The CV was used in all stages of the development of the aptasensor using a potential range of -0.5 to $+0.6 \mathrm{~V}$ and with a scan rate of $50 \mathrm{mV} \mathrm{s}^{-1}$, while SWV was only used to confirm the electrochemical behavior after each preparation step of the aptasensor development using the following conditions: amplitude $50 \mathrm{mV}$; potential range $-0.5 \mathrm{~V}$ to $+0.6 \mathrm{~V}$; scan increment $5 \mathrm{mV}$ and frequency $100 \mathrm{~Hz}$.

In both techniques, the decrease in peak current was calculated based on the relative current change $(\Delta I \%)$ considering the peak current values obtained after aptamer immobilization and protein incubation of the cyclic and SWV voltammograms recorded using the equation (1):

$\Delta I \%=\left(I_{0}-I_{1}\right) / I_{0} \times 100$

where $\Delta I$ is relative current change (\%); $I_{0}$ and $I_{1}$ represents the current before and after the sample incubation, respectively.

\section{Results and discussion}

\subsection{Isolation of DNA aptamers against rhOPN}

The SELEX procedure was used to isolate and identify DNA aptamers with affinity and specificity against rhOPN. This methodology can be used to isolate both RNA and DNA aptamers. The selection of RNA aptamers is more expensive, complex and time consuming than of DNA aptamers, mainly due to the chemical modifications required to increase its nuclease resistance, as well as to additional transcription and reverse transcription steps [52,53]. In the current work, 10 selection cycles were conducted. The bound aptamers sequences were cloned in the vector PCR2.1-TOPO and 19 clones were isolated and sequenced. These aptamers can potentially be used as biorecognition elements for the development of rhOPN aptasensors. The sequences of the isolated aptamers are typically examined taking into account their homology, lowest Gibbs energy and ability to form stable secondary structures considering the aptamer full-sequence (70 nucleotides (nt)) or the random region (30 nt). All the 19 DNA aptamer sequences exhibited a variable region with $30 \mathrm{nt}$ (Table 1 ). These sequences were further aligned based on the common trinucleotide sequence (TGT) and were classified into seven groups taking into account their homology. Although the clones C10K9, C10K3 and C10K5 only presented a partial TG nucleotide, given their homology with the group (inserted in groups II, III and V, respectively), they were included in the analysis (Table 1). Since the trinucleotide was not found in the constant regions of the sequences, these regions were not considered in the analysis. From Table 1, it can be seen that the sequences C10K2, C10K12, C10K5 and C10K20 present higher homology compared to sequences of the same group. The sequence C10K2 exhibits $80 \%$ of homology with the clones C10K1 and C10K10.

The aptamer sequences were analyzed using the MFold online tool [42]. This tool predicts their potential secondary structures calculating the lowest Gibbs free energies and the number of structures that can be formed using the same conditions as those used for the selection. Table 1 also shows the lowest Gibbs free energy values calculated taking into account both the random
(30 nt) and full sequence with conserved regions (70 nt) for all the DNA aptamers isolated. The sequences exhibiting higher Gibbs free energy values $(\Delta G)$ (i.e. lower stability) and with multiple possible secondary structures were not chosen for further characterization. Moreover, although the sequences C10K2, C10K9, C10K3, C10K7, C10K5, C10K15 and C10K18 exhibited the lowest $\Delta G$ values in the analysis with $70 \mathrm{nt}$, multiple structures could be formed. Analysing only the random region ( $30 \mathrm{nt}$ ) (Table 1 ), the sequences with the lower $\Delta G$ values were $\mathrm{C} 10 \mathrm{~K} 2, \mathrm{C} 10 \mathrm{~K} 7$ and $\mathrm{C} 10 \mathrm{~K} 15$ and these were found to form a stable secondary structure (data not shown). On the other hand, the sequence corresponding to the constant regions could be involved in the aptamers functional secondary structure conferring it stability [54,55], thus an analysis comprising these regions was also conducted. When adding parts of the conserved region to the random region it was found that only the sequences $\mathrm{C} 10 \mathrm{~K} 2, \mathrm{C} 10 \mathrm{~K} 7, \mathrm{C} 10 \mathrm{~K} 15$ and $\mathrm{C} 10 \mathrm{~K} 18$ presented an increase in the $\Delta \mathrm{G}$ value $(-4.41(35 \mathrm{nt}),-3.18(50 \mathrm{nt}),-2.65(35 \mathrm{nt})$ and -3.92 (40 nt) Kcal $\mathrm{moL}^{-1}$, respectively) and the formation of a single secondary structure (data not shown). In the stem-loop structure of this sequence, it could be observed the common trinucleotide (TGT), thus suggesting that this trinucleotide could be involved in the specific binding site to the rhOPN protein. Therefore, the C10K2 clone sequence was chosen for the following studies since it showed the lowest $\Delta G$ value and the same stable stem-loop secondary structure (Fig. 1). Stem-loop structures are important as binding regions of the DNA or RNA aptamers to their targets and the consensus motifs are often located in these structures [56]. To date, only one RNA aptamer presenting a stem-loop secondary structure was reported to specifically recognize OPN [20]. Some researchers argue that the RNA is more reliable for aptamer identification, since structures are more diverse than those obtained with DNA, mainly due to the presence of $2^{\prime}-\mathrm{OH}$ group and non-Watson-Crick base pairing in RNA. RNA aptamers are more flexible than the DNA molecules and can offer a wider range of conformational diversity. However, the RNA is more susceptible to nuclease degradation, which can restrict its use in the presence of biological fluids. On the other hand, the DNA aptamers are considered naturally more robust than RNA aptamers due to the absence of the hydroxyl group at their 2 -end [57], displaying high stability for biological applications $[52,53,55,58,59]$.

\subsection{Determination of the affinity of the isolated DNA aptamer to rhOPN}

Fluorescence binding assays are suitable methods to determine the dissociation constants of aptamer-protein complexes, and are very simple methods only requiring the modification of the aptamer with a fluorescent dye molecule $[43,60]$. The dissociation constant $\left(K_{\mathrm{d}}\right)$ of the isolated DNA aptamer $(\mathrm{C} 10 \mathrm{~K} 2)$ was determined taking into account the fluorescence intensity of the free aptamer and the aptamer-protein complex formed, using the method previously described [41]. The DNA aptamer (C10K2) was modified with 6-carboxyfluorescein (FAM). The fluorescence intensity of the free aptamer was measured at increasing concentrations of FAMDNA aptamer in solution. Fig. 2A shows the two calibration curves established for the incubation time of $30 \mathrm{~min}$ and $4 \mathrm{~h}$, respectively. The calibration curves obtained at the two time periods for the free aptamer were similar. The fluorescence intensity of the aptamer-protein complex was measured after the inoculation of the aptamer with different rhOPN concentrations. The total fluorescence of the aptamer-protein complex formed versus the rhOPN concentration is plotted in Fig. 2B. As can be inferred, the fluorescence increased with increasing rhOPN concentrations for the two abovementioned incubation periods. Moreover, it was found that the total fluorescence was greater for the assays in 
Table 1

Nucleotide sequences of the clones obtained from the $10^{\text {th }}$ cycle of selection. The sequences listed correspond to the 30 nucleotides random region ( $\left.30 \mathrm{nt}\right)$ of each ssDNA aptamer isolated. The regions were aligned based on the

TGT trinucleotide.

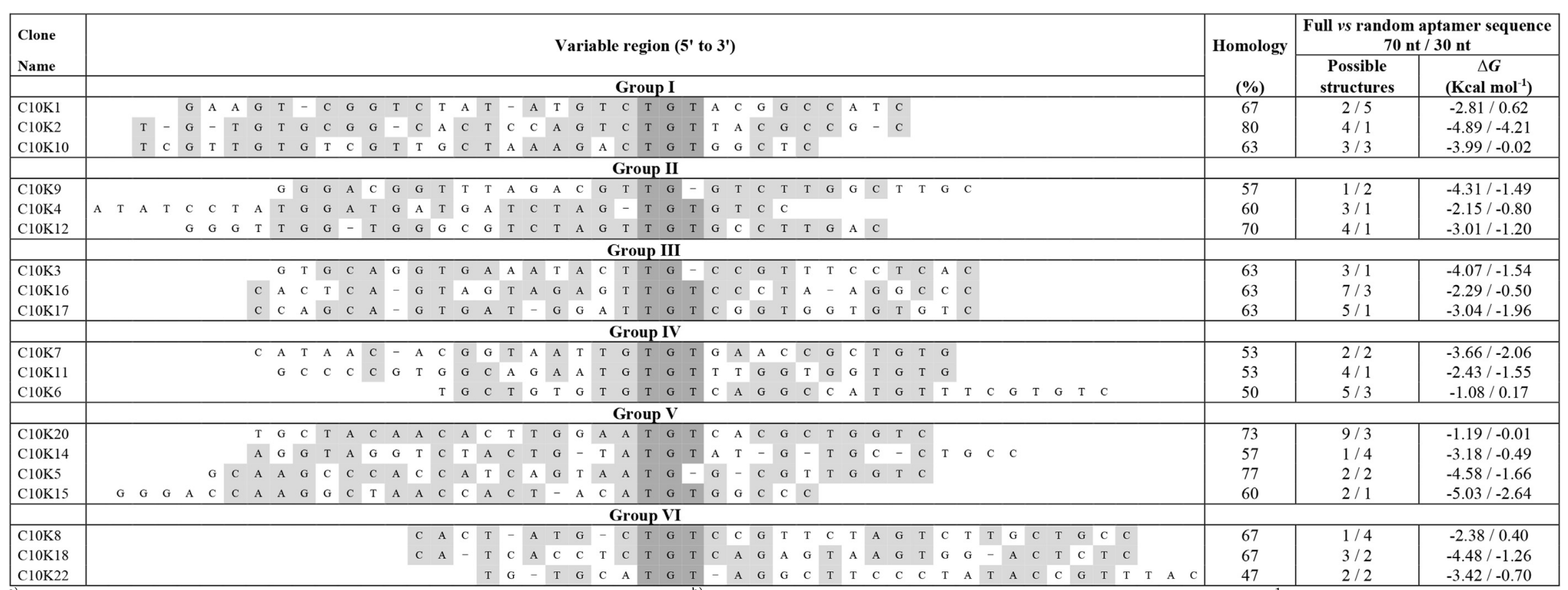

a) Aptamers selected by Systematic Evolution of Ligands by Exponential enrichment (SELEX). ${ }^{\text {b) }}$ MFold program was used to calculate the Gibbs free energy ( $\left.\Delta G\right)\left(K^{2}\right.$ cal mol $\left.{ }^{-1}\right)$, number of predicted structure using

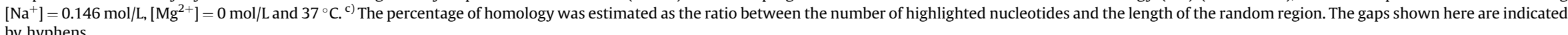
by hyphens. 

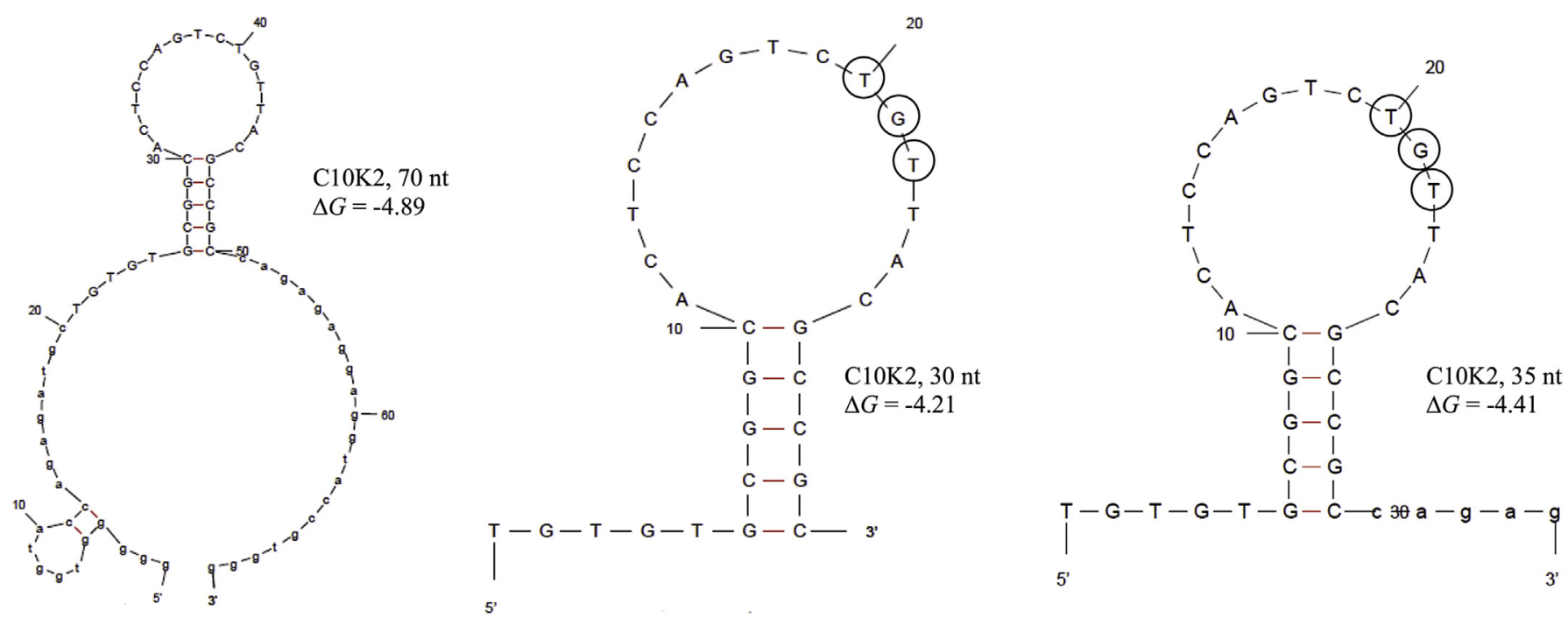

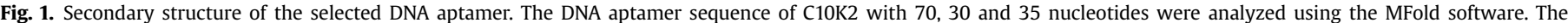

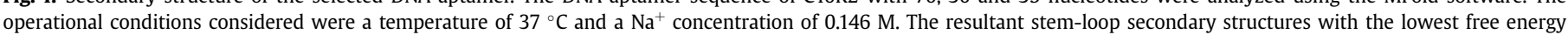
folding are shown. The conserved regions are displayed in lowercase.
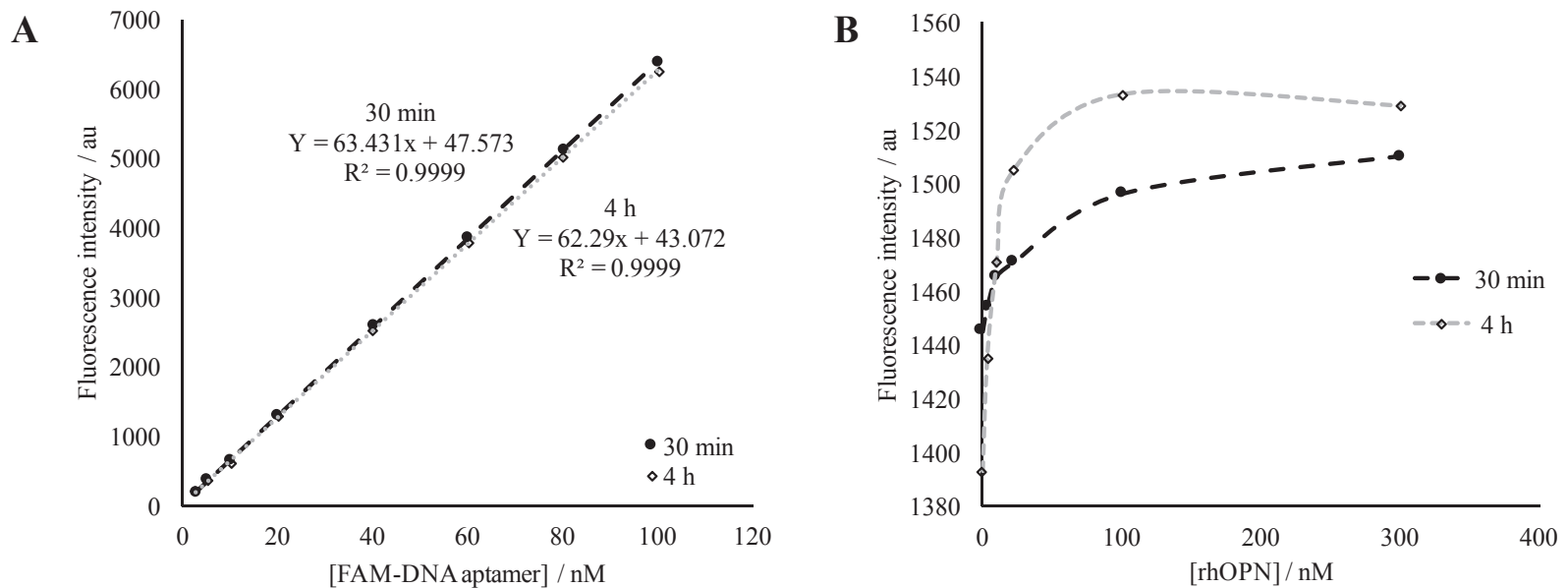

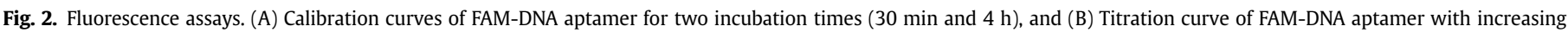
rhOPN concentrations in PBS buffer pH 7.6 at 30 min and $4 \mathrm{~h}$. The concentration of the DNA aptamer was $20 \mathrm{nM}$.

which $4 \mathrm{~h}$ of incubation was used, thus proving an increased formation of the aptamer-protein complex. However, $30 \mathrm{~min}$ of incubation was sufficient to obtain an aptamer-protein interaction. These results suggest that the total fluorescence is due to both nonbound aptamer and aptamer-rhOPN complex. Therefore, assuming that only one aptamer-rhOPN high affinity-binding site exists, $K_{\mathrm{d}}$ values of 2.5 and $1.1 \mathrm{nM}$ were estimated for $30 \mathrm{~min}$ and $4 \mathrm{~h}$, respectively. The relative standard deviation (RDS) of three experiments was lower than $5 \%$ for the two incubation periods, demonstrating that the DNA aptamer has a high affinity for rhOPN for both incubation periods studied. The $K_{\mathrm{d}}$ values herein determined for the DNA aptamer are of the same order of magnitude as those previously obtained for the RNA aptamer [41]. Furthermore, based on the standard errors of the estimated $K_{\mathrm{d}}$ values for both aptamers, no statistical significant differences were found $(P$ value $\geq 0.230$, for Z-test, for $30 \mathrm{~min}$ and $4 \mathrm{~h}$ incubation times). Nevertheless, it should be noticed that the DNA aptamer showed higher fluorescence intensities (ranging from 1390 to $1530 \mathrm{au}$ ) (Fig. 2B) than the RNA aptamer (ranging from 700 to $1200 \mathrm{au}$ ), for the same concentration levels [41].
To confirm the specificity of DNA aptamer for rhOPN, the same fluorescence experiments were conducted with other proteins (thrombin (THR), bovine serum albumin (BSA) and recombinant bovine osteopontin (rbOPN)). In these experiments, $20 \mathrm{nM}$ of DNA aptamer was incubated with different concentrations of THR, BSA and rbOPN for $30 \mathrm{~min}$ and $4 \mathrm{~h}$, respectively. No titration curves could be obtained using the total fluorescence measured after interaction of the DNA aptamer with those proteins and so, it was not possible to estimate the respective dissociation constants. Thus, it can be concluded that the DNA aptamer exhibits high specificity for rhOPN.

\subsection{Characterization of aptasensor}

The CV and SWV techniques were used to determine the electrochemical behavior and monitor each step of the aptasensor development. The Fig. 3 illustrates the voltammograms obtained by $\mathrm{CV}$ (Fig. 3A) and SWV (Fig. 3B), using the solution of $\left[\mathrm{Fe}(\mathrm{CN})_{6}\right]^{3-/ 4-}$ as electrochemical probe, for three experimental steps: bare $\mathrm{Au}$ electrode, DNA aptamer and DNA aptamer-rhOPN protein. Detailed 


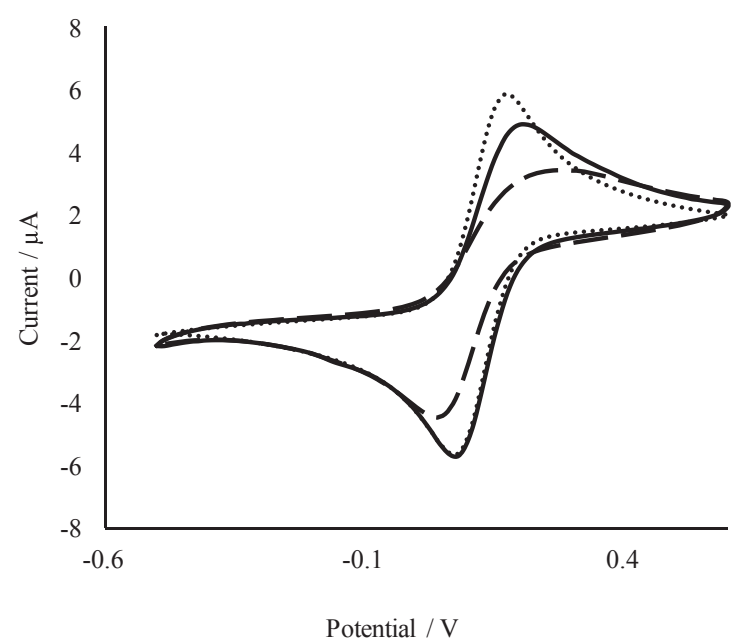

..... Bare Au electrode $\quad$ DNA aptamer $\quad-$ rhOPN

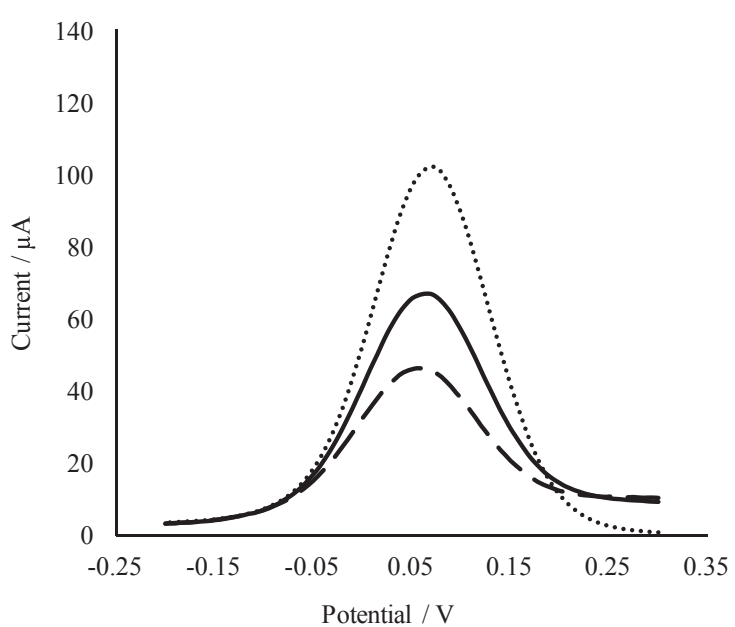

..... Bare Au electrode $\longrightarrow$ DNA aptamer $\quad-$ rhOPN

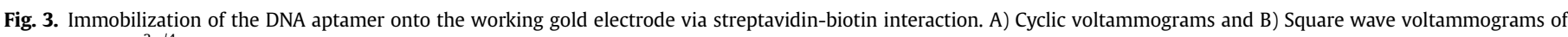

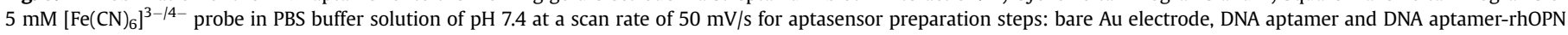
protein.

information about voltammetric changes occurring during all steps of the aptamer immobilization in the electrode surface, as well as for rhOPN detection, can be found in the supplementary material (Fig. S2 and Table S1). Globally, the voltammograms profiles for CV and SWV showed a similar trend of peak current intensities, thus evidencing that both techniques are adequate to monitor the electrochemical changes during aptamer preparation and analysis. However, since SWV (Fig. 3B) is more sensitive than CV (Fig. 3A), the differences observed between plots are more pronounced. Table 2 summarizes the electrochemical parameters, namely the potential variation between cathodic and anodic peaks $(\Delta E \mathrm{p})$, the cathodic peak current value (Ipc) and anodic peak current value (Ipa) calculated using the cyclic voltammograms and the peak current (Ip) calculated using the forward and reverse current of the square wave voltammograms. The results correspond to the mean values ( \pm standard deviation) obtained from assays using different SPGEs and prepared in different days.

A characteristic quasi-reversible electrochemical cyclic voltammogram of the $\left[\mathrm{Fe}(\mathrm{CN})_{6}\right]^{3-/ 4-}$ redox solution at the bare gold electrode was observed (Fig. $3 \mathrm{~A}$ ), with a peak-to-peak separation $\triangle E \mathrm{p}$ of $100 \mathrm{mV}$ and similar cathodic and anodic peaks current intensities (Table 2). Fig. 3B also shows that the bare gold electrode presented a high peak current intensity (Ip $102.1 \mu \mathrm{A}$ ) for the redox probe and exhibited maximum peak intensity at the potential $0.070 \mathrm{~V}$. The step corresponding to the DNA aptamer immobilization on the working electrode gold surface showed an increase of the $\triangle E \mathrm{p}$ and lower peaks current intensities compared to the bare gold electrode. This probably occurs due to the negative charges of the aptamer backbone phosphate group and $\left[\mathrm{Fe}(\mathrm{CN})_{6}\right]^{3-/ 4-}$ redox probe. Indeed, the electrostatic repulsive interaction is expected to block the electron transfer [61]. These results suggest that the DNA aptamer was successfully assembled on the working electrode gold surface. Next, the SPGE modified with the DNA aptamer was incubated with a standard rhOPN solution (1540 nM) and significant changes of the voltammograms could be observed.

In rhOPN analysis, CV technique showed the highest potential variation between peaks and the lowest peak current intensity compared with the bare gold surface electrochemical values (Table 2). Similar trends were found for the SWV analysis, in which it was observed a higher decrease of peak current intensity $(54.8 \%$ compared to that of the bare gold surface) and a lower potential value $(+0.06 \mathrm{~V})$. These significant changes observed in the two electrochemical techniques strongly evidence that the formation of the aptamer-rhOPN complex can alter the permeability of the layer towards the charged redox solution and consequently the rate of their diffusion [62]. The higher decrease (negative readout signal) in the peaks current intensities after rhOPN incubation can be associated with the high specificity of the DNA aptamer to rhOPN and this specific interaction can lead to a change of the aptamer structure and conformation.

The optimal concentration of DNA aptamer to be immobilized onto the working electrode, as well as the best incubation time for enhancing the rhOPN interaction with the surface-bound aptamer were evaluated as previously described [41]. Details regarding

Table 2

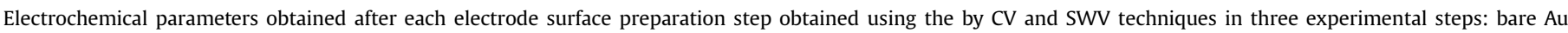
electrode, DNA aptamer and DNA aptamer-rhOPN protein.

\begin{tabular}{|c|c|c|c|c|}
\hline \multirow[t]{2}{*}{ Steps } & \multicolumn{3}{|l|}{$\mathrm{CV}$} & \multirow{2}{*}{$\frac{\text { SWV }}{I p(\mu A)}$} \\
\hline & $\Delta E \mathrm{p}(\mathrm{mV})$ & Ipa $(\mu \mathrm{A})$ & $\operatorname{Ipc}(\mu \mathrm{A})$ & \\
\hline Bare gold & $100 \pm 10$ & $6.9 \pm 0.5$ & $6.9 \pm 0.4$ & $102.1 \pm 2.9$ \\
\hline DNA aptamer & $133 \pm 6$ & $5.9 \pm 0.3$ & $6.5 \pm 0.2$ & $66.7 \pm 0.3$ \\
\hline rhOPN & $230 \pm 10$ & $4.1 \pm 0.2$ & $4.9 \pm 0.3$ & $46.2 \pm 0.2$ \\
\hline
\end{tabular}

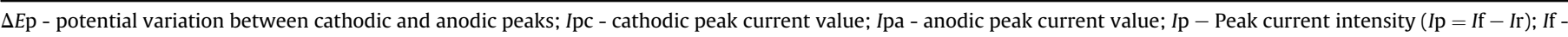
forward current; $\mathrm{Ir}$ - reverse current. 

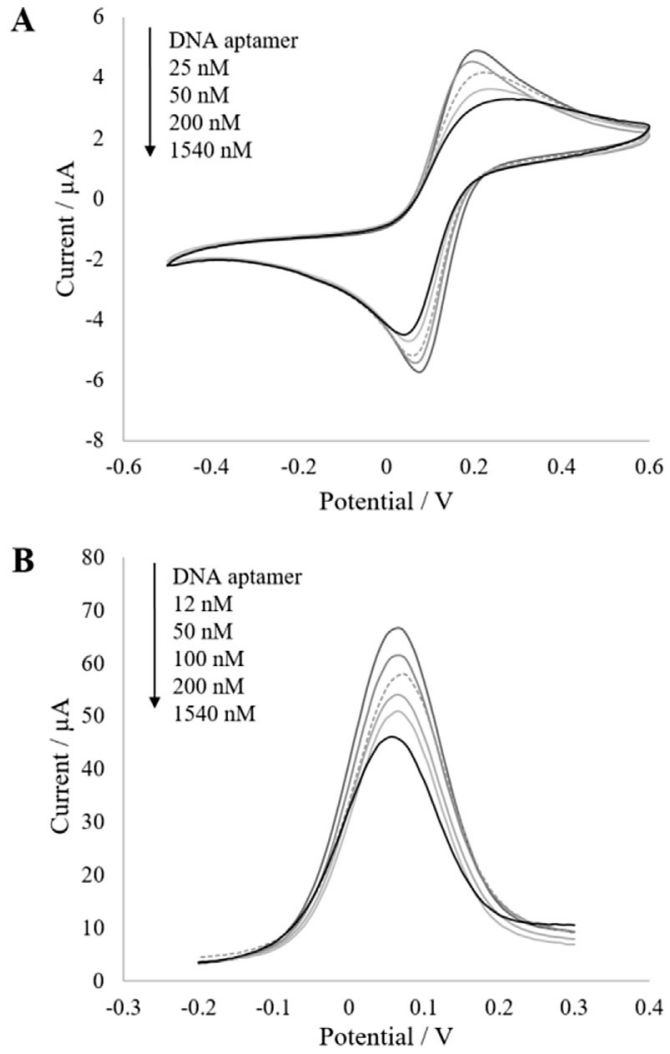

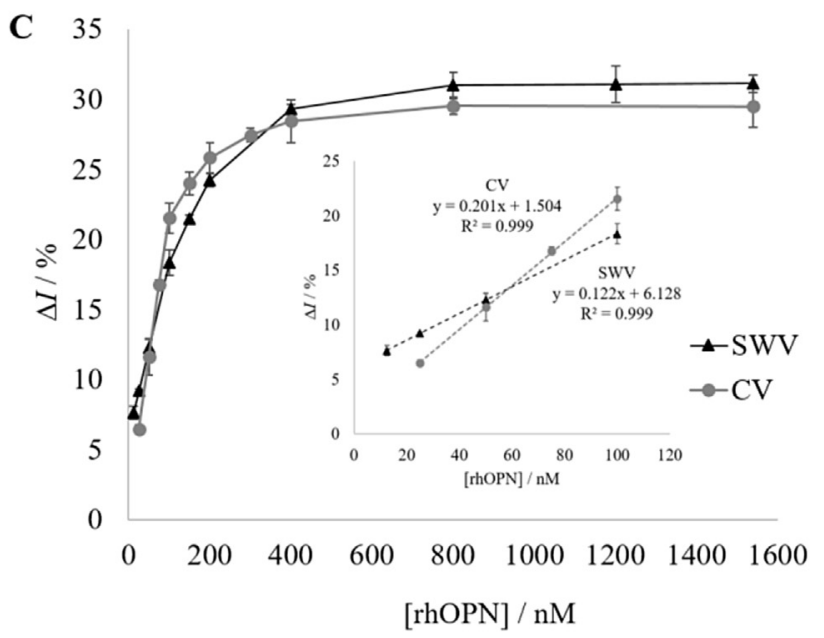

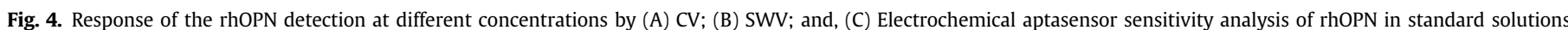

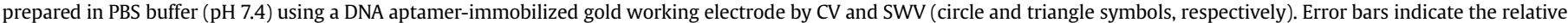
standard deviation of three independent experiments.

these optimization experiments are given as supplementary material (Fig. S1). The results showed that the optimal aptamer concentration and incubation time were $4 \mathrm{nM}$ and $60 \mathrm{~min}$, respectively. These conditions were found to be similar to those previously reported for a RNA aptamer [41].

\subsection{Evaluation of the DNA aptasensor using standard solutions}

The sensitivity of the DNA aptasensor was evaluated taking into account its response ( $\Delta I \%$ values) to standard solutions containing different amounts of rhOPN, using $[\mathrm{Fe}(\mathrm{CN}) 6]^{3-/ 4-}$ as electrochemical probe. Each rhOPN assay was carried out using different SPGEs. The $\mathrm{CV}$ and $\mathrm{SWV}$ assays showed a decrease in the current response with increasing concentrations of rhOPN (Fig. 4A and B). Fig. 4C illustrates the $\Delta I$ \% values as a function of the rhOPN concentration. The results show increasing values of $\Delta I \%$ with the increase of the rhOPN concentration, in the range between 25 and $1540 \mathrm{nM}$ for CV and between 12 and $1540 \mathrm{nM}$ for SWV, reaching signal saturation near $400 \mathrm{nM}$, for both techniques. For CV, a linear correlation could be established $\left(R^{2}=0.999\right)$ for a dynamic concentration range from 25 to $100 \mathrm{nM}(\Delta I \%=0.201( \pm 0.003) \times[\mathrm{rhOPN}, \mathrm{nM}]+1.504$ $( \pm 0.180))$. Based on the regression parameters [51], the detection and quantification limits were calculated as $2.6 \pm 0.3$ and $7.9 \pm 1.0 \mathrm{nM}\left(\sim 169 \mathrm{ng} \mathrm{mL}^{-1} \text { and } \sim 514 \mathrm{ng} \mathrm{mL}^{-1}\right)^{3}$, respectively. The linear correlation for the SWV technique could be established $\left(R^{2}=0.999\right)$ for a dynamic concentration range between 12 and

\footnotetext{
${ }^{3}$ Reported OPN levels in $\mathrm{ng} \mathrm{mL}^{-1}$ were converted to OPN levels in $\mathrm{nM}$, assuming an OPN molecular weight of $65 \mathrm{kDa}$.
}

$100 \mathrm{nM}(\Delta I \%=0.122( \pm 0.001) \times[\mathrm{rhOPN}, \mathrm{nM}]+6.13( \pm 0.04))$, being the detection and quantification limits equal to $1.4 \pm 0.4$ and $4.2 \pm 1.1 \mathrm{nM}\left(\sim 91 \mathrm{ng} \mathrm{mL}^{-1} \text { and } \sim 267 \mathrm{ng} \mathrm{mL}^{-1}\right)^{3}$, respectively. Thus, as expected, the SWV technique allowed an increase in the sensitivity of the proposed aptasensor, enabling a faster analysis with lower LOD and LOQ values compared to the CV technique. It should be pointed out that, based on the LOD and LOQ values determined and taking into account the reported values of OPN (up to $290 \mathrm{ng} \mathrm{mL} \mathrm{m}^{-1}$ ) in breast cancer patients (including in patients with metastatic and recurrent breast cancer [11]), it could be concluded that although both electrochemical techniques could be used to detect OPN levels in people suffering from cancer, only SWV could be applied for quantification purposes. In addition, compared to previous works on rhOPN detection (Table S2), the proposed DNA aptasensor exhibited a better detection limit than the RNA aptasensor previously developed by Meirinho et al. [41], but still higher than those reported by other researchers using different techniques, type of electrodes and biosensor preparation methodologies (e.g., $0.17 \mathrm{nM}$ [63] and $10.7 \mathrm{ng} \mathrm{mL}^{-1}(\sim 0.2 \mathrm{nM})^{3}$ [38]). However, it should be noticed that in the studies of Cao et al. [38] and Chen et al. [63], the working electrode surfaces were greater that those used in the RNA aptasensor of Meirinho et al. [41] and also in the DNA aptasensor herein described. Indeed, the later works envisaged the biosensor miniaturization, with a substantial impact on the amounts of reagents and samples volumes required for the detection. Finally, the use of antibody-based biosensors (immunosensors) to detect a protein presents some drawbacks such as their production, stability, modification, washing steps and reagents requirement that are sensitive to temperature and expensive [64]. Therefore, the use of aptamers still is a good alternative. 
The aptasensor stability was evaluated through the detection of the electrochemical signal of three SPGEs stored at $4{ }^{\circ} \mathrm{C}$ during different time periods. When compared with the initial $\Delta I \%$ value, the response after $5,10,15$ and 20 days was found to retain $94.3 \%$, $94.7 \%, 92.1 \%$ and $90.5 \%$ of the original value, respectively, thus demonstrating a good stability of the aptasensor response along time. The results showed that the $\Delta I \%$ only decreases about $10 \%$ of the original value after 20 days of storage in buffer at $4{ }^{\circ} \mathrm{C}$. After 10 days, the stability of the DNA aptasensor was higher than that obtained with the RNA aptasensor (that retain $88 \%$ ) previously reported [41]. This interesting gain in stability may be due to the fact that the RNA aptamer sequences are more susceptible to degradation by nucleases than the DNA aptamers [24,65]. In addition, the method herein proposed showed satisfactory intra-day repeatability. Indeed, the electrochemical signals recorded with three SPGE prepared in the same day and inoculated with $200 \mathrm{nM}$ and $1540 \mathrm{nM}$ rhOPN, showed relative standard deviations (RSD) of $4.7 \%$ and $5.7 \%$, respectively. Furthermore, the method also showed satisfactory inter-day repeatability since, for five SPGE prepared in different days, the electrochemical signals recorded for $200 \mathrm{nM}$ and $1540 \mathrm{nM}$ showed a RSD of $4.2 \%$ and 5.0\%, respectively. For evaluation the possible regeneration of the aptasensor, considering that aptamers can be denatured several times without losing its function tests using two regenerate reagents $(\mathrm{NaCl}$ and urea) $[64,66,67]$ were carried out and the $\Delta I \%$ values obtained after aptamer-protein binding (rhOPN analysis) and after incubation with the regenerate reagents, were found to be statistically the same. Therefore, the regenerate solutions used were not effective in disrupting the aptamer-protein complex without degradation of the aptamer.

The selectivity is crucial to evaluate the aptasensor performance and it can be assessed by comparing the DNA aptamer binding with the specific protein (rhOPN) and with non-specific proteins. Nonspecific binding to the aptasensor leads to high background signals, decreasing its performance. Four proteins (THR, BSA, rbOPN and LYS) were evaluated as possible interferents. These proteins were chosen taking into account their molecular weights and isoelectric points, as well as their distinctive features that can affect the aptasensor performance. THR was used since the OPN has a conserved thrombin cleavage domain (RSK (arginine ${ }^{168}$-lysine ${ }^{170}$ ) adjacent to the RGD domain) and it is a secreted serine protease found in the human blood [6,7]. BSA is inert and similar to the human serum albumin (HSA) also present in human blood [68] and in high concentrations in serum samples [69]. rbOPN was used since its cDNA sequence holds a high degree of homology with rhOPN $[4,70]$. Finally, LYS was used as a control protein since it possesses the lowest MW and highest $\mathrm{pI}$ compared with all the other proteins studied and it is known to non-specifically bind to nucleic acids [69]. The relative current response $(\Delta I \%)$ for the interferent proteins tested was found to be negligible as compared to the unique binding response obtained with rhOPN (Fig. 5). The results clearly demonstrate the great DNA aptamer sensitivity and specificity to rhOPN. This DNA aptasensor showed a better selectivity for THR, LYS and similar for rbOPN than the one obtained with the RNA aptasensor previously reported [41]. The slightly higher response towards THR may be tentatively attributed to the possible aptamer cross-reactivity, which may be enhanced since OPN contains a THR cleavage domain [7]. These results suggest that this aptasensor could be used to detect rhOPN in biological samples such as blood, plasma or serum.

\subsection{Use of the DNA aptasensor to detect rhOPN in complex synthetic and real biological samples}

The applicability of the proposed method to analyze the

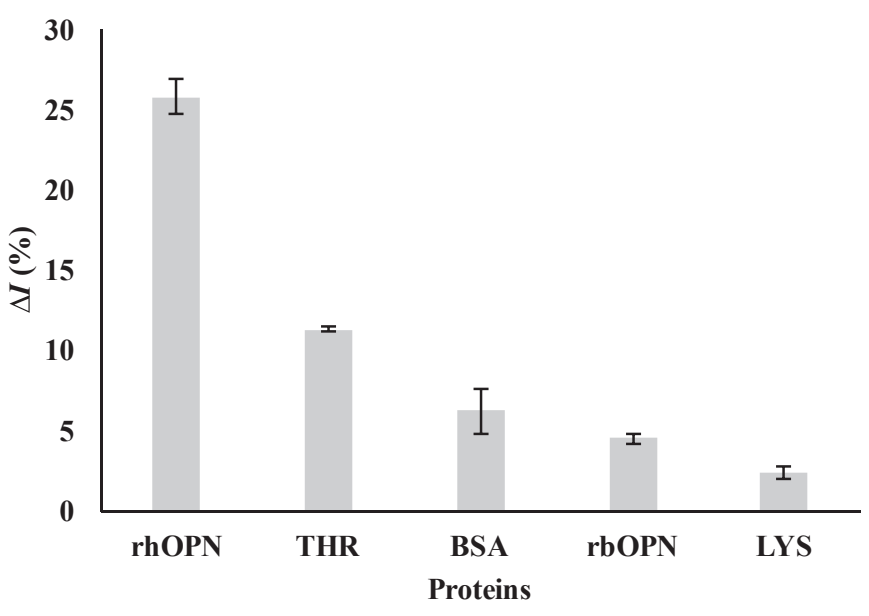

Fig. 5. The relative current response $(\Delta I \%)$ to non-specific proteins $(200 \mathrm{nM})$ : BSA bovine serum albumin, LYS - lysozyme, rbOPN - bovine osteopontin and THRthrombin and for specific-protein rhOPN - human osteopontin. Error bars correspond to the relative standard deviation of three independent experiments.

presence of rhOPN in synthetic human plasma solutions was also studied, allowing the assessment of the DNA aptasensor performance in more realistic samples. The response of the DNA aptasensor was evaluated by CV and SWV (Fig. 6A and B, respectively) showing a current intensity decrease trend with the increase of the rhOPN concentration, similarly to those previously observed for the rhOPN standard solutions prepared with PBS buffer ( $\mathrm{pH} 7.4)$. In this study, as in the study with standard solutions, the sensitivities obtained by the two electrochemical techniques used are statistically different $(P$-value $<0.001)$. Based on the calibration curves established using the synthetic plasma solutions (Fig. 6C), and contrary to $\mathrm{CV}$, it could be found that for SWV, lower detection and quantification limits $\left(1.3 \pm 0.1 \mathrm{nM}\left(\sim 85 \mathrm{ng} \mathrm{mL}^{-1}\right)^{4}\right.$ and $3.9 \pm 0.4 \mathrm{nM}$ $\left(\sim 245 \mathrm{ng} \mathrm{mL}^{-1}\right)^{4}$, respectively) were obtained as compared to the rhOPN standard solutions. The better performance observed in complex medium (i.e., human synthetic samples) strengthen the confidence that the DNA aptasensor developed coupled with SWV could be used for detecting and quantifying OPN levels in breast cancer patients, for whom levels up to $290 \mathrm{ng} \mathrm{mL}^{-1}$ have been reported. Also, for the assays with synthetic plasma samples it was verified that the slope of the calibration curve for SWV is 4 times higher than that obtained by $\mathrm{CV}$, thus confirming the expected higher sensitivity of the SWV technique.

Finally, the results of the rhOPN recovery assays (Table S3) pointed out that for both electrochemical techniques similar and satisfactory recoveries were obtained (ranging from $44.3 \%$ to $80.8 \%$ for CV and from $61.2 \%$ to $89.1 \%$ for SWV), which were in accordance with the recoveries achieved with the standard ELISA method (from $69.1 \%$ to $156.5 \%$ ). These results demonstrate that the aptasensor also presents a very satisfactory performance in the presence of complex samples, such as the synthetic human plasma.

Furthermore, a sample of human plasma was also analyzed using both methods (i.e., DNA aptasensor and ELISA method) and the results obtained for SWV showed that the aptasensor and the standard ELISA method quantified (using the standard addition method ) similar OPN levels in the real plasma sample $(2.2 \pm 0.7 \mathrm{nM}$ $\left(\sim 141 \mathrm{ng} \mathrm{mL}^{-1}\right)^{4}$ and $1.7 \pm 0.1 \mathrm{nM}\left(\sim 108 \mathrm{ng} \mathrm{mL}^{-1}\right)^{4}$, respectively). This preliminary satisfactory performance pointed out that the DNA

\footnotetext{
${ }^{4}$ Reported OPN levels in $\mathrm{ng} \mathrm{mL}^{-1}$ were converted to OPN levels in $\mathrm{nM}$, assuming an OPN molecular weight of $65 \mathrm{kDa}$.
} 

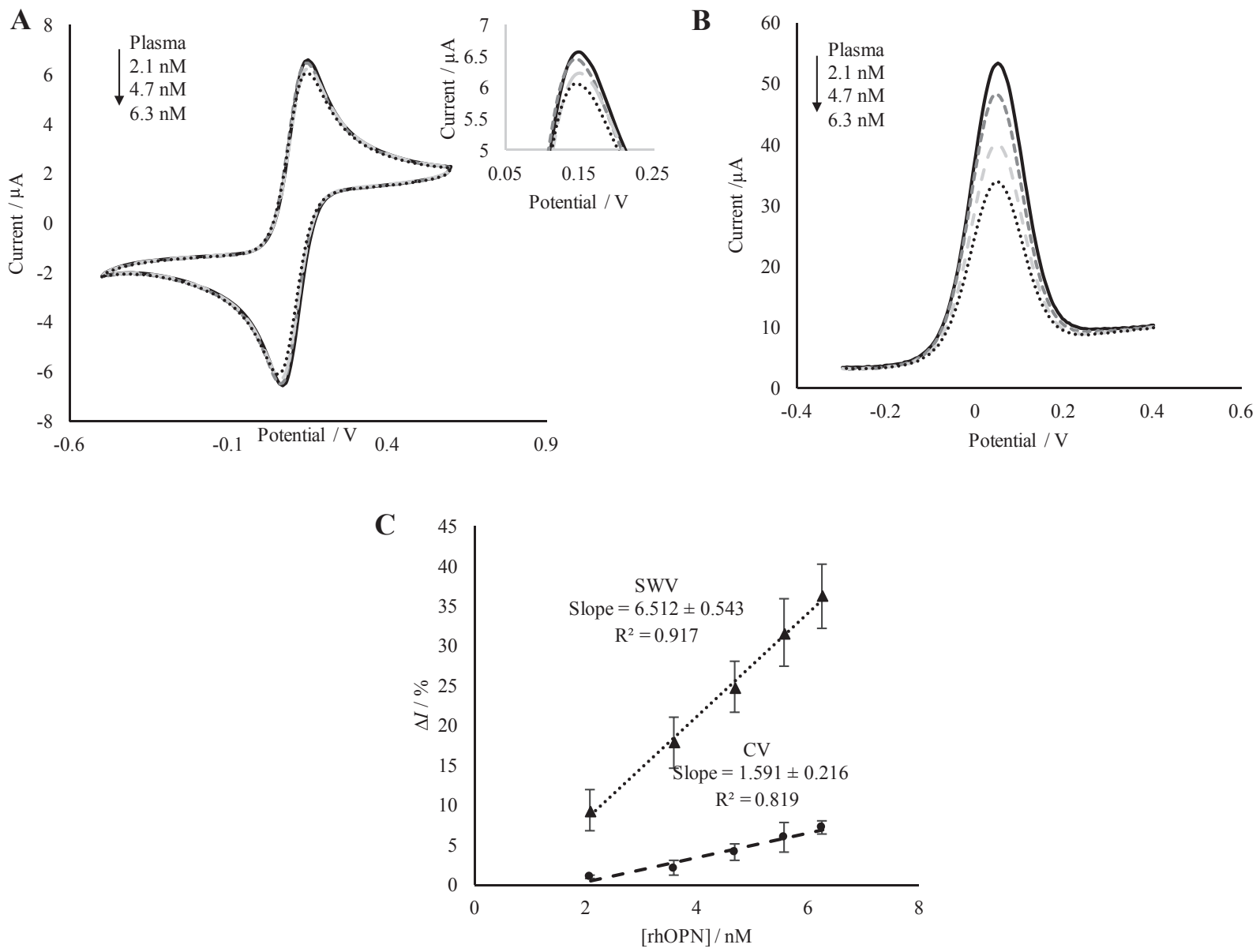

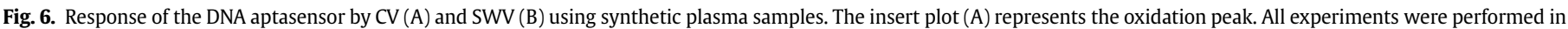
triplicate. The calibration curves based on the $\Delta I$ \% values were obtained by CV and SWV (C) and the error bars were indicated on the curve.

aptasensor could be foreseen as a promising analytical tool for the detection of rhOPN in complex biological samples and within the concentration levels expected to be found in breast cancer patients. However, further assays with additional human samples from a broader donors would be needed to validate the proposed aptasensor.

\section{Conclusions}

In this work we proposed a simple and sensitive label-free electrochemical aptasensor for the detection of rhOPN using a SPGE modified with a newly isolated DNA aptamer as the bioreceptor element. The developed aptasensor showed high sensitivity, stability and repeatability being able to detect and quantify OPN in complex biological samples solutions, within the concentration ranges usually reported in plasma samples from patients with breast cancer. A DNA aptasensor comprises an efficient and simple strategy to directly analyze relevant biomarkers in complex samples, thus enabling a fast and cheap method for diagnosis and therapy monitoring. Nevertheless, it is expected that combining this simple strategy with the use of nanomaterials, such as gold nanoparticles, could greatly increase the performance of these aptasensors. In addition, the availability of two different aptamers with different binding sites for the detection of the same protein could allow the design of different aptasensors, such as sandwich format and it could enable the development of multiplexed aptamer arrays, thus increasing the sensitivity and specificity.

\section{Acknowledgments}

The authors acknowledge the financial support from the Strategic funding of UID/BIO/04469/2013 unit and COMPETE 2020 (POCI-01-0145-FEDER-006684), and from project BioTecNorte (project number NORTE-01-0145-FEDER-000004). This work was also financially supported by Project POCI-01-0145-FEDER-006984 - Associate Laboratory LSRE-LCM and by Project UID/QUI/00616/ 2013 - CQ-VR both funded by FEDER - Fundo Europeu de Desenvolvimento Regional through COMPETE2020 - Programa Operacional Competitividade e Internacionalização (POCI) - and by national funds through FCT - Fundação para a Ciência e a Tecnologia, Portugal. S. Meirinho also acknowledges the research grant provided by Project UID/EQU/50020/2013.

\section{Appendix A. Supplementary data}

Supplementary data related to this article can be found at http:// dx.doi.org/10.1016/j.aca.2017.07.071.

\section{References}

[1] P.H. Anborgh, J.C. Mutrie, A.B. Tuck, A.F. Chambers, Pre- and post-translational regulation of osteopontin in cancer, J. Cell Commun. Signal 5 (2011) 111-122.

[2] S.P. Sase, J.V. Ganu, N. Nagane, Osteopontin : a novel protein molecule, Ind. Med. Gaz. 146 (2012) 62-66.

[3] A.B. Tuck, A.F. Chambers, A.L. Allan, Osteopontin overexpression in breast cancer: knowledge gained and possible implications for clinical management, J. Cell. Biochem. 102 (2007) 859-868. 
[4] P. Wai, P. Kuo, Osteopontin : regulation in tumor metastasis, Cancer Metastasis 27 (2008) 103-118.

[5] M. Scatena, L. Liaw, C.M. Giachelli, Osteopontin, A. Multifunctional, Molecule regulating chronic inflammation and vascular disease, Arterioscler. Thromb. Vasc. Biol. 27 (2007) 2302-2309.

[6] G. Gursoy, Y. Acar, S. Alagöz, Osteopontin: a multifunctional molecule, J. Med. Med. Sci. 1 (2010) 55-60.

[7] M.S. Beausoleil, E.B. Schulze, D. Goodale, C.O. Postenka, A.L. Allan, Deletion of the thrombin cleavage domain of osteopontin mediates breast cancer cell adhesion, proteolytic activity, tumorgenicity, and metastasis, BMC Cancer 11 (2011) 25-37.

[8] W. Likui, W. Hong, Z. Shuwen, Clinical significance of the upregulated osteopontin mRNA expression in human colorectal cancer, J. Gastrointest. Surg. 14 (2010) 74-81.

[9] M. Ahmed, G.C. Kundu, Osteopontin selectively regulates p70S6K/mTOR phosphorylation leading to NF-kappaB dependent AP-1-mediated ICAM-1 expression in breast cancer cells, Mol. Cancer 9 (2010) 101-124.

[10] M. Bache, M. Kappler, H. Wichmann, S. Rot, A. Hahnel, T. Greither, H.M. Said, M. Kotzsch, P. Würl, H. Taubert, D. Vordermark, Elevated tumor and serum levels of the hypoxia-associated protein osteopontin are associated with prognosis for soft tissue sarcoma patients, BMC Cancer 10 (2010) 132-140.

[11] V.H.C. Bramwell, A.B. Tuck, J.-A.W. Chapman, P.H. Anborgh, C.O. Postenka, W. Al-Katib, L.E. Shepherd, L. Han, C.F. Wilson, K.I. Pritchard, M.N. Pollak, A.F. Chambers, Assessment of osteopontin in early breast cancer: correlative study in a randomised clinical trial, Breast Cancer Res. 16 (2014) R8.

[12] M. Mirza, E. Shaughnessy, J.K. Hurley, K.A. Vanpatten, G.A. Pestano, B. He G.F. Weber, Osteopontin-c is a selective marker of breast cancer, Int. J. Cancer 122 (2008) 889-897.

[13] L.R. Rodrigues, J.A. Teixeira, F.L. Schmitt, M. Paulsson, H. Lindmark-Mansson, The role of osteopontin in tumor progression and metastasis in breast cancer, Cancer Epidemiol. Biomarkers Prev. 16 (2007) 1087-1097.

[14] K. Ohno, H. Nishimori, T. Yasoshima, K. Kamiguchi, F. Hata, R. Fukui, K. Okuya, Y. Kimura, R. Denno, S. Kon, T. Uede, N. Sato, K. Hirata, Inhibition of osteopontin reduces liver metastasis of human pancreatic cancer xenografts injected into the spleen in a mouse model, Surg. Today 40 (2010) 347-356.

[15] A. Macrì, A. Versaci, G. Lupo, G. Trimarchi, C. Tomasello, S. Loddo, G. Sfuncia, R. Caminiti, D. Teti, C. Famulari, Role of osteopontin in breast cancer patients, Tumori 95 (2009) 48-52.

[16] G.F. Weber, G.S. Lett, N.C. Haubein, Osteopontin is a marker for cancer aggressiveness and patient survival, Br. J. Cancer 103 (2010) 861-869.

[17] G.F. Weber, G.S. Lett, N.C. Haubein, Categorical meta-analysis of Osteopontin as a clinical cancer marker, Oncol. Rep. 25 (2011) 433-441.

[18] V.H.C. Bramwell, G.S. Doig, A.B. Tuck, S.M. Wilson, K.S. Tonkin, A. Tomiak, F. Perera, T.A. Vandenberg, A.F. Chambers, Serial plasma osteopontin levels have prognostic value in metastatic breast cancer, Clin. Cancer Res. 12 (2006) $3337-3343$

[19] Y.-Y. Xu, Y.-Y. Zhang, W.-F. Lu, Y.-J. Mi, Y.-Q. Chen, Prognostic value of osteopontin expression in breast cancer: a meta-analysis, Mol. Clin. Oncol. 3 (2014) 357-362.

[20] Z. Mi, H. Guo, M.B. Russell, Y. Liu, B. a Sullenger, P.C. Kuo, RNA aptamer blockade of osteopontin inhibits growth and metastasis of MDA-MB231 breast cancer cells, Mol. Ther. 17 (2009) 153-161.

[21] L.R. Rodrigues, N. Lopes, B. Sousa, D. Vieira, F. Milanezi, Significance of osteopontin expression in human invasive breast tumour stroma, Open Breast Cancer J. 1 (2009) 1-9.

[22] P.H. Anborgh, S.M. Wilson, A.B. Tuck, E. Winquist, N. Schmidt, R. Hart, S. Kon, M. Maeda, T. Uede, L.W. Stitt, A.F. Chambers, New dual monoclonal ELISA for measuring plasma osteopontin as a biomarker associated with survival in prostate cancer: clinical validation and comparison of multiple ELISAs, Clin. Chem. 55 (2009) 895-903.

[23] P.H. Anborgh, J.C. Mutrie, A.B. Tuck, A.F. Chambers, Pre-and post-translational regulation of osteopontin in cancer, J. Cell Commun. Signal 5 (2011) 111-122.

[24] B. Prieto-Simón, M. Campàs, J.-L. Marty, Electrochemical aptamer-based sensors, Bioanal. Rev. 1 (2010) 141-157.

[25] B. Strehlitz, N. Nikolaus, R. Stoltenburg, Protein detection with aptamer biosensors, Sensors 8 (2008) 4296-4307.

[26] S.G. Meirinho, L.G. Dias, A.M. Peres, L.R. Rodrigues, Voltammetric aptasensors for protein disease biomarkers detection: a review, Biotechnol. Adv. 34 (2015) $941-953$.

[27] A. Ravalli, D. Voccia, I. Palchetti, G. Marrazza, Electrochemical, electrochemiluminescence, and photoelectrochemical aptamer-based nanostructured sensors for biomarker analysis, Biosensors 6 (2016) 39-59.

[28] S.N. Topkaya, M. Azimzadeh, M. Ozsoz, Electrochemical biosensors for cancer biomarkers detection: recent advances and challenges, Electroanalysis 28 (2016) 1402-1419.

[29] M. Jarczewska, Ł. Górski, E. Malinowska, Electrochemical aptamer-based biosensors as potential tools for clinical diagnostics, Anal. Methods 8 (2016) $3861-3877$

[30] J.R. Kanwar, R.R. Mohan, R.K. Kanwar, K. Roy, R. Bawa, Applications of aptamers in nanodelivery systems in cancer, eye and inflammatory diseases, Nanomedicine (Lond) 5 (2010) 1435-1445.

[31] R. Stoltenburg, N. Nikolaus, B. Strehlitz, Capture-SELEX: selection of DNA aptamers for aminoglycoside antibiotics, J. Anal. Methods Chem. 2012 (2012) $1-14$.

[32] A. Sett, S. Das, P. Sharma, U. Bora, Aptasensors in health, environment and food safety monitoring, Open J. Appl. Biosens. 1 (2012) 9-19.

33] M. Ye, J. Hu, M. Peng, J. Liu, J. Liu, H. Liu, X. Zhao, W. Tan, Generating aptamers by cell-SELEX for applications in molecular medicine, Int. J. Mol. Sci. 13 (2012) 3341-3353.

[34] M.A. Syed, S. Pervaiz, Advances in aptamers, Oligonucleotides 20 (2010) 215-224.

[35] T. Hianik, J. Wang, Electrochemical aptasensors-recent achievements and perspectives, Electroanalysis 21 (2009) 1223-1235.

[36] A.-E. Radi, Electrochemical aptamer-based biosensors: recent advances and perspectives, Int. J. Electrochem 2011 (2011) 1-17.

[37] K.-M. Song, S. Lee, C. Ban, Aptamers and their biological applications, Sensors 12 (2012) 612-631.

[38] Y. Cao, D. Chen, W. Chen, J. Yu, Z. Chen, G. Li, Aptamer-based homogeneous protein detection using cucurbit[7]uril functionalized electrode, Anal. Chim. Acta 812 (2014) 45-49.

[39] I. Palchetti, M. Mascini, Electrochemical nanomaterial-based nucleic acic aptasensors, Anal. Bioanal. Chem. 402 (2012) 3103-3114.

[40] T. Yu, J. Li, Q. Liu, W. Cheng, D. Zhang, H. Ju, S. Ding, Electrochemical aptasensor based on klenow fragment polymerase reaction for ultrasensitive detection of PDGF-BB, Int. J. Electrochem. Sci. 7 (2012) 8533-8542.

[41] S.G. Meirinho, L.G. Dias, A.M. Peres, L.R. Rodrigues, Development of an electrochemical RNA-aptasensor to detect human osteopontin, Biosens. Bioelectron. 71 (2015) 332-341.

[42] M. Zuker, Mfold web server for nucleic acid folding and hybridization prediction, Nucleic Acids Res. 31 (2003) 3406-3415.

[43] D.T. Tran, K.P.F. Janssen, J. Pollet, E. Lammertyn, J. Anné, A. Van Schepdael J. Lammertyn, Selection and characterization of DNA aptamers for egg white lysozyme, Molecules 15 (2010) 1127-1140.

[44] A.S.R. Potty, K. Kourentzi, H. Fang, G.W. Jackson, X. Zhang, G.B. Legge, R.C. Willson, Biophysical characterization of DNA aptamer interactions with vascular endothelial growth factor, Biopolymers 91 (2009) 145-156.

[45] J. Cohen, P. Cohen, S.G. West, L.S. Aiken, Applied Multiple Regression/Correlation Analysis for the Behavioral Sciences Third Edition, third ed., Lawrence Erlbaum Associates, Mahwah, New Jersey, 2003.

[46] T. Hianik, V. Ostatná, M. Sonlajtnerova, I. Grman, Influence of ionic strength, $\mathrm{pH}$ and aptamer configuration for binding affinity to thrombin, Bioelectrochemistry 70 (2007) 127-133.

[47] D.-J. Chung, K.-C. Kim, S.-H. Choi, Electrochemical DNA biosensor based on avidin-biotin conjugation for influenza virus (type A) detection, Appl. Surf. Sci. 257 (2011) 9390-9396.

[48] N. Paniel, J. Baudart, A. Hayat, L. Barthelmebs, Aptasensor and genosenso methods for detection of microbes in real world samples, Methods 64 (2013) 229-240.

[49] L. Zhou, M.-H. Wang, J.-P. Wang, Z.-Z. Ye, Application of biosensor surface immobilization methods for aptamer, Chin. J. Anal. Chem. 39 (2011) 432-438, http://dx.doi.org/10.1016/S1872-2040(10)60429-X.

[50] V. Ostatná, H. Vaisocherová, J. Homola, T. Hianik, Effect of the immobilisation of DNA aptamers on the detection of thrombin by means of surface plasmon resonance, Anal. Bioanal. Chem. 391 (2008) 1861-1869.

[51] J. Ermer, J. Miller, Method Validation in Pharmaceutical Analysis. A Guide to Best Practice, Wiley-VCH GmbH and co. KGaA, 2005.

[52] S. Tombelli, M. Minunni, M. Mascini, Analytical applications of aptamers Biosens. Bioelectron. 20 (2005) 2424-2434.

53] P. Dua, S. Kim, D. ki Lee, Nucleic acid aptamers targeting cell-surface proteins, Methods 54 (2011) 215-225.

[54] A. Ozer, J.M. Pagano, J.T. Lis, New Technologies provide quantum changes in the scale, speed, and success of SELEX methods and aptamer characterization, Mol. Ther. - Nucleic Acids 3 (2014) e183.

[55] Y.S. Kim, M.Y. Song, J. Jurng, B.C. Kim, Isolation and characterization of DNA aptamers against Escherichia coli using a bacterial cell-systematic evolution of ligands by exponential enrichment approach, Anal. Biochem. 436 (2013) 22-28.

[56] R. Stoltenburg, C. Reinemann, B. Strehlitz, SELEX - a ( r ) evolutionary methoc to generate high-affinity nucleic acid ligands, Biomol. Eng. 24 (2007) $381-403$.

[57] C. Marimuthu, T.-H. Tang, J. Tominaga, S.-C. Tan, S.C.B. Gopinath, Singlestranded DNA (ssDNA) production in DNA aptamer generation, Analyst 137 (2012) 1307-1315.

[58] A.V. Kulbachinskiy, Methods for selection of aptamers to protein targets Biochemistry 72 (2007) 1505-1518.

[59] V.J.B. Ruigrok, M. Levisson, M.H.M. Eppink, H. Smidt, J. van der Oost, Alternative affinity tools: more attractive than antibodies? Biochem. J. 436 (2011) $1-13$

[60] X. Fang, Z. Cao, T. Beck, W. Tan, Molecular aptamer for real-time oncoprotein platelet-derived growth factor monitoring by fluorescence anisotropy, Anal. Chem. 73 (2001) 5752-5757.

[61] G.S. Bang, S. Cho, B.G. Kim, A novel electrochemical detection method for aptamer biosensors, Biosens. Bioelectron. 21 (2005) 863-870.

[62] Y.S. Kim, J.H. Niazi, M.B. Gu, Specific detection of oxytetracycline using DNA aptamer-immobilized interdigitated array electrode chip, Anal. Chim. Acta 634 (2009) 250-254.

[63] H. Chen, Q. Mei, S. Jia, K. Koh, K. Wang, X. Liu, High specific detection of osteopontin using a three-dimensional copolymer layer support based on electrochemical impedance spectroscopy, Analyst 139 (2014) 4476-4481.

[64] Y. Liu, N. Tuleouva, E. Ramanculov, A. Revzin, Aptamer-based electrochemica 
biosensor for interferon gamma detection, Anal. Chem. 82 (2010) 8131-8136.

[65] A. Sassolas, L.J.J.J. Blum, B.D.D.D. Leca-Bouvier, D. Lyon, Electrochemica aptasensors, Electroanalysis 21 (2009) 1237-1250.

[66] C. Ocaña, M. Pacios, M. del Valle, A reusable impedimetric aptasensor for detection of thrombin employing a graphite-epoxy composite electrode, Sensors 12 (2012) 3037-3048.

[67] A.-E. Radi, J.L. Acero Sánchez, E. Baldrich, C.K. O'Sullivan, Reagentless, reusable, ultrasensitive electrochemical molecular beacon aptasensor, J. Am. Chem. Soc. 128 (2006) 117-124.
[68] S. Xie, R. Yuan, Y. Chai, L. Bai, Y. Yuan, Y. Wang, Label-free electrochemical aptasensor for sensitive thrombin detection using layer-by-layer self-assembled multilayers with toluidine blue-graphene composites and gold nanoparticles, Talanta 98 (2012) 7-13.

[69] G. Gokulrangan, J.R. Unruh, D.F. Holub, B. Ingram, C.K. Johnson, G.S. Wilson, DNA aptamer-based bioanalysis of IgE by fluorescence anisotropy, Anal. Chem. 77 (2005) 1963-1970.

[70] P.Y. Wai, P.C. Kuo, The role of osteopontin in tumor metastasis, J. Surg. Res. 121 (2004) 228-241. 